cases in which previous modes of treatment, of almost every possible kind, hud been found to fail. ${ }^{*}$

I will now bring to a close the observations which I have put together on the subject. To resume: After continuing to use the galium in several cases subsequent to my first visit to the Asile at Tain, I determiner to py a stennd visit in the autumn of last year, hoping to find the expectations regarding the evlargement of the institucion real zed. This $I$ dill in Angust, but found that in most respec s things were much in the same condition as when I was there previously. Sone slight alterations had been effected, hat I did not learn that the accommoriation for patients bad been to any great degree enlarged. One patient whom I mentionerl as having met and talked with at nyy first visit, in $1<53$, was still there, deriving. as he thought, benefit; and I was glad to find that they were building a handsome solid stone chapel for the use of the Asile. apart from the building itself. This wis proviled with two separate larice recesses, for the accom molation of patients when attacked with seizures during Dirine service. I have no doubt that not only will the provision of a chapel conduce to the comfort of the patieats, but that the arministrations connected therewith will contribute towards the suecess of the general treatinent nursuer. I believe that the non-accomplishment of the contemplated enlargemert of nperations is owing to the calls upon public sympathy being less rearlily responded to than was anticipated. Moreover, I found that Dr. Pialli, whom I before described as having contributer by his courtesy towarls my understiandiner so much of what was being rlone there, harl left the neizhbourhood. In his place was Dr. Perriat, a gentle man practising at Tournon, who kindly showed me several cases of much interest amongst the inmates.

As regurds the galium, I found that since my previous visit in addition to the pâtes, two otber preparations of the juice were marie-namely, one combined with ch colate, and one in the form of a syrup. These were male for the converience of those who visited the Asile periorlically; to be used, like the lozenges, $t$ in the interval. The syrup is sold under the term, "Sirop anti-suasmodique," and is described as having been employed with success in all affections of the nervous system, in the case of irritable persons, and of those who are fatigued after prolonge l exertions, or by chronic disease. It is said to possess to some degree the arlvantages of opinm withont its inconveniences, "calming, without actin: upon the brain," producing quiet nights, and replacing all $n$ rcotic preparations, "which" it is said, "ourbt always to be excluned from the treatment of nervous aff ctions." It is to be taken moraing and evening, two hours before and after fook, in doses of one or two tablesyoonfuls, in an infusion either of the lime or orange. leaves. Moreover 1 found that since my previons risit, $M$. Larnage bal had prepared a number of questions, printed on paper, to be answered by patients who apply for relief. so that in time he mily procure a series of regular and valuahle stat istical observations. The questions are on the following hears:Name, resiltence, age, profession, hight, state of life (marrird or not). trmperament, character, state of intelligence, state of memory, hea'th of father and mother or canse of their death, age at which the attacks appeared, canse of at.tacks, perion of time of thtir occurrence, at what intervals, mode of access of the attacks, duration of attacks, condiiion of yatients after the attacks, what remedies have heen nsed and with what effect, whether the attacks occur in the day or nirht. It is clear that replies to these queries from so many patients as come to Tain twice a year, would furnish interesing scientific results; yet

* I would here allude to a popular deseription of the galium system of cure recommen ed at riain, whiph 1 have jingt hat printed cut to ine, to be found in a little reriu ieal called "The Monthly Proket" (sce number for

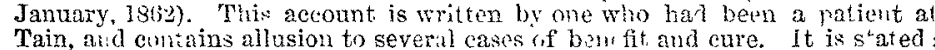
Tain, aid cutains allusion to several cases of bent fit and cure. It is s'ated

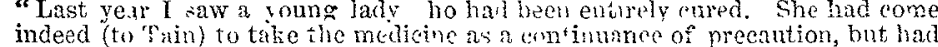

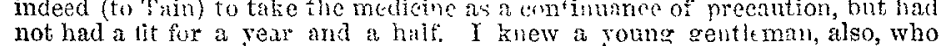
not had a lit fur a vear and a half. I knew a young gentleman, also, who came to stay at the Hispice, where, als, tirere wis at the time anofer
Englishman. Both vere cured. In the litter thit I have i eforred to before there is an aceount of a Fiench priest of ronlonse, who had become quite

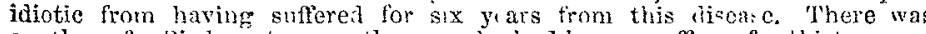
another of a pi-dmontese gentleman, who had bien a sufferer for thirty years, and was rednetd to the same melaneloly condition. By the persevering use,
however, of this system both were eventually cured : therr faveulies were rcstored, and they were a ble to resume in it orcupations."

t As in the case of the râtes or lozenges of galuum, the syrup and chocolate are only to lie bought at the Pharm cie du Bu eau de Biestai-ance, Muivin de Secours des Seeurs de St. Vincent de Paul, where it is soll fir the god of the poor, and given gratuitously to all who can produee a certificate of poverty, signed by the mayor and euré of their district, and of the rpileptic nature of
their case by the phyeician. The lozenges are sold at three francs a box, their case hy the phyeician. "The lozenges are suld at three franes a box,
containing twenty-fouir. The "sirop" is sold in bottles, at eight and four franes each, of about the size of wine bottles. considering the amount and kind of research which has been of late devoted to the study of epilepsy and kindred affections, and the numerous alliances and connexions which it has been found to possess, more comprehensive and particular questions might advantageonsly have been proposed in adrlition.

Such, then, is the sum of the information which $I$ am in the position to offer regarding the Asile at Tain, and what may be called the galium treatment there afforded. I will not now be so bold as to give any definite opmion regarding the claims of the treatment npon the attention of the protession. Whether the supposed anti.epileptic rirtues of the galium are due to eliminarive or to sedative properties-or whether, indeed, the method of treatment auipted derives any considerable measure of its success from the galium, or is only valuable by reason of the hygienic accompaniments, the attention to diet, the well-ordere life in reference to extrcise, sleep, mental emotions. \&c., reculation of the secretions, \&c., which are very strictly enforced ${ }^{*}$ - I will not take upon myself to determine. I am well aware of the valuable effects of these bygienic and common-sense precautions in the treatment of epil-psy, what ever strictly therapeutic line is followed out (advantages which, however, the coowds who flock to Tain yearly can hardly be sunposed to possess to any extent); and $I$ also well know what effect. of a longer or shorter duration, the use of anything like a new remedy has upon many patients. Yet, with all these considerations, $I$ have felt that the manner in which the galium treatment has been from time to time for many years spoknn of, artl the use of it in my own hauds, afforled ample reason for its being well considered and bronght prominently forward, in order that, by abundant and simultaneous trials in diverse cases and under varions circumstances, its expected properties-the rationale of its action-may be thoroughly tested. $\nmid$

I would press the galium album upon the attention of the profession as at any rate not wholly unworthy of trial, not merely in reference to epilepsy, but also in reference to other diseases in which the class of remedies termed sedatives and anti spasmodics are usually cousidered necessary.

Upper Brook-street, May, 1862.

\section{CASES IN PRACTICE.}

\section{BY FREDERICK DALTON, EsQ, M.R.C.S.}

TuE following cases have lately been under my care, and may, perhaps, be of some interest :-

The first case is that of a laty, aged sixty, single, suffering from a painful sore at the side of the right labia minora. It commenced early in Fobruary, 1859, slowly increased, and $r$ sisted the usuial remedies, including caustic and black-wash externally, with mercury and opium internally. By the month of May the sore was about an inch and a half in diameter, situated on indurated tissue, the edges $\epsilon$ verted, with a slight irritating discharge. It severe lancinating pain rendered the contact of dressing unbearable.

Nay 14ch, 1859 - I commenced using a lotion, composed of one drachm of trisnitrate of bismuth, witl an ounce and a half of olive oil, to be dropped on to the sore every hour or two; my patient taking a draught containing five grains of joctide of potassium three times a lay. In the course of a few days the pain somewhat liminished; and at the end of three weeks the sore looked less anhealthy. The treatment was continued till October, when the sore was completely healed.

The second case is one of cancer, occurring in the breast of the bousekeeper of the above lady. The patient was unmarried, aged forty-nine. Mensirnation had ceaserl two years previously. A swelling was first observed in July, 1 1>61. This

* "Aer, esca, quies, repletia, gzudi 'scmnus-,

tree moderata juvant, immoterata noent."

I find from the Pharmueutical Juarnal and Transactions, edited by Jacob Bell, vol. xii, p. 190, 1802-3, that Rubrt Sthwarz ana'yzed the galium verum, and fiund it to contain the same principles as the salum ap ininei.e, bevides chlorophyll, starch matter, and other prineiples common to all plants, three distinct acids-namely, a variety of tannin which he terms gallitannic acid, citric acid, ard a pecnliar acid previonsly discurered by Schwart and Roch'eder, and nam d rubluhloric acid. Now it must be remembered that the uses of the galium aparine have long been known as aperient, duretic, and antiscorbutie (see Woud and Bache's Dirvensatory of the United States of America, eleventh edition, 1855, p.1414). Possibly, from all this, the view that the action of galum verum or mollugo is elimmative, may receive strength Another variety, the galium rotundifolium, was considered as to its medical pr pertlè, which are dear iked as bring " "blood-puritying," in an Inaugural
Dissertation by Selig at Erlangen in 1802 . 
slowly increased till the middle of December, when its growth became more rapid. When first examined on the 3rd of Jan. last, it felt as a hard, irregular, rounded mass, about four inches in diameter, and free, except at the portion to which the nipple was retracted.* The superficial veins were enlarged, and the integuments becoming slightly inflamed. The axillary glands were not affected.

On the 9th of January (my patient objecting to chloroform) I removed the tumour by transfixing the breast for the outer flap, and then dissecting as usual. On the third day the wound was healed, with the exception of a small portion, which has since granulated healthily.

Under the microscope the tumour exhibits the cells con. sidered diagnostic of cancer. My patient, who is in good health, is now taking liquor arsenicalis, in small doses, with her meals.

Doughty-street, May, 1862 .

\section{If atlitror}

OF THE PRACTICE OF

\section{MEDICINE AND SURGERY IN THE}

\section{HOSPITALS OF LONDON.}

Nulla est alia pro certo noscendi via, nisi quam plurimas et morborum $t \mathrm{t}$ dissectionum historias, tam aliorum proprias, collectas habere $\epsilon$ t inter se cor parare-MORGAGI. De Sed. et Cano. Morb., lib. 14. Procenium.

\section{GUY'S HOSPITAL.}

CARCINOMA OF THE SPINE, HEART, INTESTINES, AND OTHER ORGANS, IN A BOY AGED FIFTEEN YEARS; PARAPLEGIA; DEATH.

(Under the care of Dr. REES.)

THe following case is full of interest on account of its ex treme rarity. The spinal symptoms were maniftsted only five weeks before admission, having produced complete para plegia. The reader will obtain much information, with the details of several cases of cancer affecting the spinal column, meninges, and medulla, in Dr. Walshe's valuable nonograph on this disease. This physician mentions, that when cardiac cancer is associated with cancer elsewhere, it is always secondary; and of twenty-five cases which he had brought to gether, in two only was it affirmed to be limited to the heart.

Samuel J-, aged fifteen, was admitted into John ward on the $171 \mathrm{~h}$ of Decemuer, 1861. Abont five weeks before this he began to feel pain in his back, and soon afterwards weakness in his legs. This had increased to total yaralysis when he was admitted. There wis paraplegia, of motion complete, and 1 ss of sensation as high as the kuees. The paralysis gradually increased upwards until the respiration became affected, but the arms remained free. A tumour could be felt in the lower part of the abdomen. He died on the 31 st.

A utopsy, twenty four hours after derith. - The body was spare, and on the buttock was a sli,ht bed-sore. Spine: On cutting through the skin, a mass of cancer was seen infiltrating the muscles over the upper part of the dorsal region. This cancer had penetrated between the arches of the vertebræ, and had entered the spinal cord. To the onter surface of the sheath at this part cancerous growths were artached. On opening the sheath the arachnold appeared quire healtby, and the cancer had not entered. At one or two spots on the cord slight projections existed, which suguested the presence of some distinct deposits of cancer; as, however, the cord was here much soft. ened, this was not satisfactorily ascertained. On passing the finger along the whole length of the cord, the projections in the cervical and lumbar regions $u$ ere found to be of their na

* '1 his nipple, and the one of the other breast, had been retraded some years. tural hardness; but the whole of the cord between these was remarkably soft. When incised, the softened medullary matter squeezed out in a semifluid form. This was most apparent in the upper part of the forsum, where the disease existed out. side. Numerous granular bodies were seen by the microscope.The lungs were in a state of chronic lobular pneumonia. The lower lobe was solidified, the section showing masses of grey hepatization scattered through them. and the intervening tissue the subject of a more recent inflammation. No cancer was discernible. The heart contained the usual coagula; but growing from the septum auriculorum was a carcinomatous tumour about the size of a small walnut, and attached by its long axis. It grew from the lower border of the foramen ovale, and projected into the right auricle. This growth did not appear in any way to interfere with the heart's action. Abdomen: At the lower part of the belly, and lying more on the right side, was a tumour covered by omentum. On re. moving the latter, it was found quite movable, being a cancerous growth of the large intestine. The tumour was about the size of a closed fist, and was formed by cancer of the coats of the bowel and cancer of the mesentery and its glands. On cutting through the intestine, the disease was seen to affect its coats throughout, and the intwstire, being distended, formed a arge cancerous surface the size of the open hand. The walls were nearly a third of an inch in thickness, and apparently composed entirely of the new substance. The inncous mem. brane was in parts destroyed, but the peritoneal coat remained, the disease appearing through it as a milk-white tumour. The walls of the diseased part were very hard, and the cancer did not suddenly cease by a defined edge, but was continued up. wards and downwards in the submucous coat; and, as a consequence, the valvulæ conniventes. being thus infiltrated, projected as hard ridges across the bowel. The mucous membrane being here intact, it required the finger to feel how the usually soft folds of mucous membrane had become cbanged into these hardened ridges. The cancer extended into the mesentery, and some of the neighbouring glands were enlarged. The ad ventitious substance was soft, but did not emit so opaque and milky a juice as in the most marked cerebriform; it appeared to contain much delicate fibrous tissue. At this part it was not apparent in which tissue the distase had commenced; but a short distance from it, another portion of bowel was affected in a less degree, which clearly showed that the disease had commenced in the coats themselves. A white hard mass, about the size of a haif crown, was observed in the coats of the intestine, and, on cutting open the bowel, this was seen to be formed in the costs opposite the mesentery. It had not quite encircled the bowd, and thus the side attacher to the mesentery was free. The mucous and serous mombrates being free, the disease appearell to be formed in the sub-tissne either of mucous or serous nembrane. The disease was situated at about the lower end of the jejunum. The liver and spleen rere healthy. Kidneys contrined several large nodulas of canuer. Poth testes contined cancer, or rather the epididymis of both, and the vas deferens of the left.

\section{CANCER HOSPITAT.}

CARCLYOMA OF TIU SPINE AND OF BOTI BREASTS;

$$
\text { FATAL RESULT. }
$$

\section{(Under the care of Mr. WEEDEN COOKE.)}

J. B--, aged forty-five, was admitted in A pril, 1560, with scirrhus of both breasts. The induration was extending across the sternal interval, the "scimlie en quluques" of Velpeau. She itm iroved in her geveral health, and no progress in the disease was apparent until about two months after armission, when she began to complain of pain in the region of the first lumbar vertebra, with much loss of power in the lower extremities. This increased until she became quite unable to rise from or turn in her bed; faintings and great general prostration of strength, with sleepless nights, supervened, and she lost all appetite for food. The howels acted with great difficulty, but there was no retention of uine. 'There was slight eularyement over the first lumbar vertebra, and pain on pressure. Unfortunately no post-mortem examination was obtained in this case. She wished to go home to fie, and that event happened a few days after she left the hospital. Although the proof u as wanting, the symptoms notably pointed to cancerous deposit in or around the lower part of the spinal cord. 